\title{
Towards efficient crude oil degradation by a Mixed bacterial consortium
}

K.S.M. Rahman ${ }^{\mathrm{a} *}$, J. Thahira Rahman ${ }^{\mathrm{a}}$, P. Lakshmanaperumalsamy ${ }^{\mathrm{b}}$, I.M. Banat ${ }^{\mathrm{a}}$

${ }^{a}$ Biotechnology Group, School of Environmental Studies, University of Ulster, Coleraine -BT52 1SA, Northern Ireland, UK

${ }^{b}$ Department of Environmental Sciences, Bharathiar University, Coimbatore - 641 046, Tamilnadu, India

* Corresponding Author

Dr K.S.M. Rahman

Biotechnology Research Group,

School of Biological and Environmental Sciences,

University of Ulster, Coleraine, County Londonderry,

Northern Ireland, BT52 1SA

Tel: UK ++ 44(2870) 323132

Fax: UK ++ 44 (2870) 324911

Email: ksmrahman@yahoo.com 


\section{Abstract}

A laboratory study was undertaken to assess the optimal conditions for biodegradation of $\mathrm{BH}$ crude oil. Among 130 oil degrading bacterial cultures isolated from oil contaminated soil samples, Micrococcus sp. GS2-22, Corynebacterium sp. GS5-66, Flavobacterium sp. DS5-73, Bacillus sp. DS6-86 and Pseudomonas sp DS10129 were selected for the study based on the efficiency of crude oil utilisation. A mixed bacterial consortium prepared using the above strains was also used. Individual bacterial cultures showed less growth and degradation than did the mixed bacterial consortium. At $1 \%$ crude oil concentration, the mixed bacterial consortium degraded a maximum of $78 \%$ of $\mathrm{BH}$ crude oil. It was followed by $66 \%$ by Pseudomonas sp. DS10129, 59\% by Bacillus sp. DS6-86, 49\% by Micrococcus sp. GS2-22, 43\% by Corynebacteriumsp. GS5-66 and $41 \%$ by Flavobacterium sp. DS5-73. However the percentage of degradation by the mixed bacterial consortium decreased from $78 \%$ to $52 \%$ as the concentration of crude oil was increased from $1 \%$ to $10 \%$. Temperature of $30^{\circ} \mathrm{C}$ and $\mathrm{pH} 7.5$ were found to be optima for maximum biodegradation.

Kew words: Biodegradation; Crude oil; Mixed bacterial consortium; Optimum conditions

\section{Introduction}

Petroleum hydrocarbon continues to be used as the principle source of energy. Wide scale production, transport, use and disposal of petroleum globally has made it a major contaminant in both prevalence and quantity in the environment. During accidental spills, action will be taken to remove or remediate or recover the contaminant immediately, whereas in gasoline stations, the spills due to leakage may be small but continuous and prolonged. Because of this persistence, chances for contamination of the 
groundwater are higher. The traditional methods to cope with oil spills are confined to physical containment. Biological methods can have an edge over the physico-chemical treatment regimes in removing spills as they offer in situ biodegradation of oil fractions by the microorganisms (Ferrari et al., 1996).

Bioremediation is suggested for treating contaminated soil sites because of its low cost and ability to convert contaminants to harmless end products. Bioremediation can be described as the conversion of chemical compounds by living organisms, especially microorganisms, into energy, cell mass and biological waste products. The rates of uptake and mineralization of many organic compounds by a microbial population depends on the concentration of the compound (Olivera et al., 1997). High concentrations of hydrocarbons can be associated with heavy, undispersed oil slicks in water, cause inhibition of biodegradation by nutrient or oxygen limitation or through toxic effects exerted by volatile hydrocarbons.

Temperature influences petroleum biodegradation by its effect on the physicochemical properties of the oil, rate of hydrocarbon metabolism by microorganisms and composition of the microbial community (Atlas, 1981). Extreme $\mathrm{pH}$ conditions are expected to have a negative influence on the ability of microbial populations to degrade hydrocarbons. Since the fate of petroleum hydrocarbons in the environment is largely determined by the local environmental conditions, which influence rates of microbial growth and enzymatic activities, this research is carried out to explore the possibility of the use of selected bacterial cultures and a mixed bacterial consortium formed by these cultures to degrade $\mathrm{BH}$ crude oil at various $\mathrm{pH}$, temperature and oil concentrations. 


\section{Methods}

\subsection{Isolation and Identification of bacterial cultures}

Soil samples were collected from gasoline and diesel spilled gas station soil in presterilised glass bottles and transported to the laboratory for analysis. Enrichment and isolation procedure of oil degrading bacterial culture was done using Mineral salts medium (Kennedy et al 1975) with crude oil as substrate and serial dilution-agar plating technique on nutrient agar medium (HIMEDIA) respectively. The isolated bacterial cultures were characterised depending on their morphological and biochemical characteristics (Holt et al. 1994).

\subsection{Preparation of Inoculum}

The bacterial cultures (12 h old) were inoculated in Mineral salts medium with $1 \%$ BH crude oil as carbon source. It was kept in the shaker at $200 \mathrm{rpm}$ at $30^{\circ} \mathrm{C}$ for a period of seven days. The growth was recorded depending on the extent of turbidity at $620 \mathrm{~nm}$ (data not given). The bacterial isolates, which exhibited excellent growth on crude oil Micrococcus sp. GS2-22, Bacillus sp. DS6-86, Corynebacterium sp. GS5-66, Flavobacterium sp. DS5-73 and Pseudomonas sp. DS10-129 were selected. A loopful of overnight culture was inoculated to $100 \mathrm{ml}$ sterile nutrient broth. The flasks were kept in a shaker at $200 \mathrm{rpm}$ for $12 \mathrm{~h}$ at $30^{\circ} \mathrm{C}$. Equal volumes (approximately equal number of live cells) of the culture broths from the above five isolates were mixed to prepare mixed bacterial consortium. 


\subsection{Biodegradation of crude oil}

Individual bacterial cultures and mixed bacterial consortium from overnight culture broths (1.0 \%) at its log phase were transferred to $250 \mathrm{ml}$ conical flasks, each containing $100 \mathrm{ml}$ of sterile defined mineral salts medium with $1 \% \mathrm{BH}$ crude oil. The flasks were incubated in a shaker at $200 \mathrm{rpm}$ at $30^{\circ} \mathrm{C}$ for 20 days. At every 2 days interval, set of flasks were used for the enumeration of microbial population by pour plate technique on plate count agar (Hi-Media, India) and estimation of crude oil content by the method of Rahman et al. (2002). The total hydrocarbons in the treatments were determined spectrophotometrically. Samples from different treatments were mixed with an equal volume of toluene to extract hydrocarbons. The extracted hydrocarbons were detected spectrophotometrically at $420 \mathrm{~nm}$. A standard curve prepared using known concentrations of crude oil was used to estimate the amount of hydrocarbons in the samples. Degradation was estimated as the difference between the initial and final concentrations of total hydrocarbons. This method of determination was selected, as no gas chromatographic facilities were available at the time.

\subsection{Effect of $p H$ on bacterial growth and biodegradation}

The effect of hydrogen ion concentration on the growth and degradation of $1 \%$ BH crude oil was studied. Mineral salts medium with BH crude oil was prepared at $\mathrm{pH}$ 6.5, 7.5, 8.5 and 9.5 using $1 \mathrm{~N} \mathrm{HCl} / 1 \mathrm{~N} \mathrm{NaOH}$. The flasks were inoculated with bacterial cultures (individual and mixed bacterial consortium) and incubated at $30^{\circ} \mathrm{C}$. The population and percentage degradation of $\mathrm{BH}$ crude oil at different time intervals were estimated. 
2.5 Effect of temperature on bacterial growth and biodegradation

The influence of temperature $\left(15^{\circ} \mathrm{C}, 30^{\circ} \mathrm{C}\right.$ and $\left.45^{\circ} \mathrm{C}\right)$ on the growth and degradation of crude oil by the bacterial isolates (individual and mixed bacterial consortium) at different time intervals were studied using mineral salts medium with $1 \%$ $\mathrm{BH}$ crude oil at $\mathrm{pH}$ 7.5. The population and percentage of degradation were determined.

2.6 Effect of various concentrations of crude oil on bacterial growth and biodegradation

Biodegradation of $\mathrm{BH}$ crude oil with selected isolates and mixed bacterial consortium were performed with various concentrations of crude oil such as $1,2.5,5$, 7.5 and $10 \%$. For all the concentrations, the experiment was conducted at $30^{\circ} \mathrm{C}$ and a $\mathrm{pH}$ 7.5. The inoculated flasks were incubated and bacterial population and degradation were estimated.

\section{Results and Discussion}

The enrichment and isolation procedure resulted in 130 pure cultures able to grow in mineral salts medium (MSM) with crude oil as carbon source. Out of 130 isolates, 50.77\%, 24.61\%, 20.77\% and 3.85\% showed low growth (0.21-0.4 OD), moderate growth (0.41-0.6 OD), high growth (0.61-0.8 OD) and excellent growth (0.81-1.0 OD) at $620 \mathrm{~nm}$ respectively (Table 1 ). The isolated crude oil degraders belong to the genera Micrococcus, Corynebacterium, Bacillus, Enterobacteriaceae, Pseudomonas, Alcaligenes, Flavobacterium, Moraxella, Aeromonas, Acinetobacter and Vibrio. The flora reflects the normal heterotrophic bacteria present in soil and native genera seem to be crude oil utilizers. However, the dominant strains belong to Corynebacterium, Bacillus, Micrococcus and Pseudomonas. The ecological studies of Lal and Khanna 
(1996) and Bharathi and Vasudevan (2001) also identified the above genera among hydrocarbon degrading microorganisms.

In our study the efficiency of crude oil degradation of the individual bacterial cultures and the designed bacterial consortium were tested and the results clearly showed that mixed bacterial consortium could carry out maximum of $78 \%$ of degradation after 20 days of incubation. By the addition of metabolically active hydrocarbon utilising microorganisms, the lag period before the indigenous microbial populations respond to the addition of a complex mixture such as crude oil can be reduced considerably (Del'Arco and de Franca, 1999; Bharathi and Vasudevan, 2001). Several other workers (Chhatre et al., 1996; Sugiura et al., 1997; Vasudevan and Rajaram, 2001) have described the ability of mixed bacterial consortia to degrade $28-51 \%$ of saturates and $0-18 \%$ of aromatics present in crude oil or up to $60 \%$ crude oil.

$\mathrm{pH} 7.5$ was found favourable for all the bacterial isolates and mixed bacterial consortium except for strain Flavobacterium sp. DS5-73 which showed the maximum percentage of degradation (43\%) at $\mathrm{pH}$ 8.5. The higher proportions of crude oil was degraded by mixed bacterial consortium followed by Pseudomonas sp. DS10-129, Bacillus sp. DS6-86, Micrococcus sp. GS2-22, Corynebacterium sp. GS5-66 and Flavobacterium sp. DS5-73 with 66\%, 59\%, 49\%, 43\% and 41\% respectively at pH 7.5. Neutral pH of 7.0 has been reported to be optimal for biodegradation (Salmon et al., 1998) and extremes in $\mathrm{pH}$ were shown to have a negative influence on the ability of microbial populations to degrade hydrocarbons (Rahman et al., 1999; Meredith et al., 2000). At $\mathrm{pH} 7.5$, population increased with time. A population of $9 \times 10^{8} \mathrm{CFU} / \mathrm{ml}$ in mixed bacterial consortium and $2.7 \times 10^{8} \mathrm{CFU} / \mathrm{ml}$ in Pseudomonas sp. DS10-129 were recorded. Other bacterial isolates showed progressive degradation from 41 to $59 \%$ and 
correspondingly the number of bacteria also increased. Hence the $\mathrm{pH} 7.5$ was selected for further experiments.

Temperature influences petroleum biodegradation by its effect on the physical nature and chemical composition of the oil, rate of hydrocarbon metabolism by microorganisms and composition of the microbial community (Atlas, 1981). All the five individual isolates and mixed bacterial consortium showed maximum crude oil degradation at $30^{\circ} \mathrm{C}$ and population also correspondingly increased. At low temperature, viscosity of the oil is increased, volatilization of alkanes reduced and the water solubility decreased, delaying the onset of biodegradation (Olivera et al., 1997). Percentage of degradation was generally observed to decrease with decreasing temperature. Higher temperature increased the rate of hydrocarbon metabolism to a maximum, typically in the range of $30^{\circ} \mathrm{C}$ to $40^{\circ} \mathrm{C}$, above that the membrane toxicity of hydrocarbons was increased (Bossert and Bartha, 1984). A temperature of $30^{\circ} \mathrm{C}$ has been reported to be optimum for microbial growth and PAH degradation (Banat, 1995). Sugiura et al. (1997) reported that Acinetobacter sp. $\mathrm{T}_{4}$ and $8 \mathrm{mS}$ degraded $20-34 \%$ of Arabian light crude oil, $14-27 \%$ of Dubai crude oil, $14-25 \%$ of Shengai crude oil and $12-19 \%$ of Maya crude oil at $20^{\circ} \mathrm{C}$ and is higher when compared to the values noticed at $5^{\circ} \mathrm{C}$. Since all our isolates were mesophilic in nature, they all exhibited optimum activity at $30^{\circ} \mathrm{C}$.

The effects of crude oil concentrations on the growth of individual bacterial cultures and mixed bacterial consortium and crude oil degradation were tested. At 2.5\% BH crude oil, mixed bacterial consortium showed 70\% degradation followed by $67 \%$ at $5 \%, 63 \%$ at $7.5 \%$ and $52 \%$ at $10 \%$ (Table 2). Rambeloarisoa et al. (1984) showed that crude oil degradation was inversely proportional to the concentration of oil. Compounds such as saturates, aromatics and polar compounds present in different crude 
oil samples are degraded at different degrees by the same organisms (Tzarkova and Groudeva, 2000). The degradability was not solely determined by the chemical structure but other factors as well. The bioavailability of these compounds in different crude oil samples may differ. Saturated compounds having a molecular weight larger than 500 may not be degraded by the organisms, since this size corresponds to the exclusion size for passage through the outer membrane of Gram-negative bacteria (Sugiura et al., 1997).

Bioremediation has an edge over other treatment methods because it can efficiently destroy the pollutant hydrocarbons present and doesn't allow the contaminant to accumulate. The present study clearly showed that by using the mixed bacterial consortium which can efficiently degrade the crude oil components, temperature of $30^{\circ} \mathrm{C}$ and $\mathrm{pH}$ of 7.5 maximum percentage of degradation can be achieved. Hence we suggest the use of the above optimised conditions and the mixed bacterial consortium for bioremediation of crude oil contaminated sites.

\section{Acknowledgements}

K.S.M. Rahman wishes to thank the Council of Scientific and Industrial Research, New Delhi, India for the award of Senior Research Fellowship. Thanks also to Environment and Heritage Service, DOE for FRDF financial support under the Northern Ireland Single Programme (Ref. WM47/99).

\section{References}

Atlas, R.M., 1981. Microbial degradation of petroleum hydrocarbons, an environmental perspective. Microbiol. Rev. 45, 180-209.

Banat, I.M., 1995. Biosurfactants production and use in microbial enhanced oil recovery and pollution remediation: A Review. Bioresource Technol. 51, 1-12. 
Bharathi, S., Vasudevan, N., 2001. Utilization of petroleum hydrocarbons by Pseudomonas fluorescens isolated from petroleum contaminated soil. Environ. Int. 26, 413-416.

Bossert, I., Bartha, R., 1984. The fate of petroleum in soil ecosystems. In: Atlas, R.M., (Ed.) Petroleum Microbiology. Macmillan Pub. Co, New York, pp. 434476.

Chhatre, S., Purohit, H.J., Shanker, R., Khanna, P., 1996. Bacterial consortia for crude oil spill remediation. Water Sci. Technol. 34, 187-193.

Del'Arco, J.P., de Franca, F.P., 1999. Biodegradation of crude oil in sandy sediment. Int. Biodeter. Biodeg. 44, 87-92.

Ferrari, M.D., Neirotti, E., Albornoz, C., Mostazo, M.R., Cozzo, M., 1996. Biotreatment of hydrocarbons from petroleum tank bottom sludge in soil slurries. Biotechnol. Lett. 18, 1241-1246.

Kennedy, R.S., Finnerty, W.R., Sudarsanan, K., Young, R.A., 1975. Microbial assimilation of hydrocarbons - the fine structure of a hydrocarbon oxidizing Acinetobacter sp. Arch. Microbiol. 102, 75-83.

Lal, B., Khanna, S., 1996. Degradation of crude oil by Acinetobacter calcoaceticus and Alcaligenes odorans. J. Appl. Bacteriol. 81, 355-362.

Meredith, W., Kelland, S.J., Jones, D.M., 2000. Influence of biodegradation on crude oil acidity and carboxylic acid composition. Organic Geochem. 31, 1059-1073.

Olivera, N.L., Esteves, J.L., Commendatore, M.G., 1997. Alkane biodegradation by a microbial community from contaminated sediments in Patagonia, Argentina. Int. Biodeter. Biodeg. 40, 75-79.

Rahman, K.S.M., Vasudevan, N., Lakshmanaperumalsamy, P., 1999. Enhancement of biosurfactant production to emulsify different hydrocarbons. J. Environ. Poll. 6, 87-93.

Rahman, K.S.M., Banat, I.M., Thahira, J., Thayumanavan, T., Lakshmanaperumalsamy, P., 2002. Bioremediation of Gasoline contaminated soil by a bacterial consortium amended with poultry litter, coir pith and rhamnolipid biosurfactant. Bioresource Technol. 81, 25-32.

Rambeloarisoa, E., Rontani, J.F., Giusti, G., Duvnjak, Z., Bertrand, J.C., 1984. Degradation of crude oil by a mixed population of bacteria isolated from sea surface foams. Marine Biol. 83, 69-81.

Salmon, C., Crabos, J.L., Sambuco, J.P., Bessiere, J.M., Basseres, A., Caumette, P., Baccou, J.C., 1998. Artificial wetland performances in the purification efficiency of hydrocarbon wastewater. Water Air Soil Pollut. 104, 313-329.

Sugiura, K., Ishihara, M., Shimauchi, T., Harayama, S., 1997. Physicochemical properties and biodegradability of crude oil. Environ. Sci. Technol. 31, 45-51. 
Tzarkova, E.K., Groudeva, V.I., 2000. Bioremediation of petroleum - Polluted soils by adsorptive immobilized Cornyebacterium sp RB-96. Biotechnol. Biotechnological Equipment. 14, 72-75.

Vasudevan, N., Rajaram, P., 2001. Bioremediation of oil sludge contaminated soil. Env. Int. 26, 409-411. 
Table 1. Biodegradation of various concentrations of BH crude oil by pure bacterial cultures and mixed bacterial consortium

\begin{tabular}{|c|c|c|c|c|c|c|c|c|c|c|}
\hline \multirow{4}{*}{ Bacteria } & \multicolumn{10}{|c|}{ Crude oil concentration (\%) } \\
\hline & +2 & & \multicolumn{2}{|c|}{2.5} & \multicolumn{2}{|c|}{5} & \multicolumn{2}{|c|}{7.5} & \multicolumn{2}{|c|}{10} \\
\hline & \multicolumn{2}{|c|}{ Incubation (days) } & & & & & & & & \\
\hline & 0 & 20 & 0 & 20 & 0 & 20 & 0 & 20 & 0 & 20 \\
\hline Micrococcus sp. GS2-22 & $\begin{array}{c}0(\mathrm{a}) \\
3 \times 10^{2}(\mathrm{~b})\end{array}$ & $\begin{array}{c}49 \\
4.4 \times 10^{7}\end{array}$ & $\begin{array}{c}0 \\
1 \times 10^{2}\end{array}$ & $\begin{array}{c}40 \\
4.1 \times 10^{8}\end{array}$ & $\begin{array}{c}0 \\
1.8 \times 10^{2}\end{array}$ & $\begin{array}{c}35 \\
3.9 \times 10^{8}\end{array}$ & $\begin{array}{c}0 \\
1.9 \times 10^{2}\end{array}$ & $\begin{array}{c}32 \\
5.6 \times 10^{9}\end{array}$ & $\begin{array}{c}0 \\
3.7 \text { X } 10^{2}\end{array}$ & $\begin{array}{c}29 \\
7.8 \times 10^{10}\end{array}$ \\
\hline Corynebacterium sp. GS5-66 & $\begin{array}{c}0 \\
2.1 \times 10^{2}\end{array}$ & $\begin{array}{c}59 \\
2.8 \times 10^{8}\end{array}$ & $\begin{array}{c}0 \\
5.7 \times 10^{2}\end{array}$ & $\begin{array}{c}51 \\
4 \times 10^{8}\end{array}$ & $\begin{array}{c}0 \\
5.3 \times 10^{2}\end{array}$ & $\begin{array}{c}44 \\
9.3 \times 10^{8}\end{array}$ & $\begin{array}{c}0 \\
2.1 \times 10^{2}\end{array}$ & $\begin{array}{c}37 \\
3.8 \times 10^{9}\end{array}$ & $\begin{array}{c}0 \\
5.7 \times 10^{2}\end{array}$ & $\begin{array}{c}32 \\
8.9 \times 10^{9}\end{array}$ \\
\hline Flavobacterium sp. DS5-73 & $\begin{array}{c}0 \\
4.8 \times 10^{2}\end{array}$ & $\begin{array}{c}43 \\
5.9 \times 10^{7}\end{array}$ & $\begin{array}{c}0 \\
3.7 \times 10^{2}\end{array}$ & $\begin{array}{c}39 \\
9.4 \times 10^{8}\end{array}$ & $\begin{array}{c}0 \\
5.6 \times 10^{2}\end{array}$ & $\begin{array}{c}31 \\
3.3 \times 10^{8}\end{array}$ & $\begin{array}{c}0 \\
2.0 \times 10^{2}\end{array}$ & $\begin{array}{c}27 \\
3.4 \times 10^{9}\end{array}$ & $\begin{array}{c}0 \\
1.9 \times 10^{2}\end{array}$ & $\begin{array}{c}18 \\
5.3 \times 10^{9}\end{array}$ \\
\hline Bacillus sp. DS6-86 & $\begin{array}{c}0 \\
7.3 \times 10^{2}\end{array}$ & $\begin{array}{c}41 \\
3.1 \times 10^{6}\end{array}$ & $\begin{array}{c}0 \\
4.0 \times 10^{2}\end{array}$ & $\begin{array}{c}32 \\
5.3 \times 10^{7}\end{array}$ & $\begin{array}{c}0 \\
9.4 \times 10^{2}\end{array}$ & $\begin{array}{c}24 \\
1.8 \times 10^{8}\end{array}$ & $\begin{array}{c}0 \\
3.7 \times 10^{2}\end{array}$ & $\begin{array}{c}21 \\
3.1 \times 10^{8}\end{array}$ & $\begin{array}{c}0 \\
6.4 \times 10^{2}\end{array}$ & $\begin{array}{c}16 \\
7.8 \times 10^{9}\end{array}$ \\
\hline Pseudomonas sp. DS10-129 & $\begin{array}{c}0 \\
2.1 \times 10^{2}\end{array}$ & $\begin{array}{c}66 \\
2.7 \times 10^{8}\end{array}$ & $\begin{array}{c}0 \\
2.8 \times 10^{2}\end{array}$ & $\begin{array}{c}54 \\
1.1 \times 10^{8}\end{array}$ & $\begin{array}{c}0 \\
4.8 \times 10^{2}\end{array}$ & $\begin{array}{c}47 \\
9.3 \times 10^{8}\end{array}$ & $\begin{array}{c}0 \\
4.8 \times 10^{2}\end{array}$ & $\begin{array}{c}36 \\
7 \times 10^{9}\end{array}$ & $\begin{array}{c}0 \\
3.3 \times 10^{2}\end{array}$ & $\begin{array}{c}27 \\
1.7 \times 10^{11}\end{array}$ \\
\hline Mixed consortium & $\begin{array}{c}0 \\
2.9 \times 10^{2}\end{array}$ & $\begin{array}{c}78 \\
9 \times 10^{8}\end{array}$ & $\begin{array}{c}0 \\
4.8 \times 10^{2}\end{array}$ & $\begin{array}{c}70 \\
6.8 \times 10^{9}\end{array}$ & $\begin{array}{c}0 \\
1.7 \times 10^{2}\end{array}$ & $\begin{array}{c}67 \\
5.6 \times 10^{9}\end{array}$ & $\begin{array}{c}0 \\
6.3 \times 10^{2}\end{array}$ & $\begin{array}{c}63 \\
9 \times 10^{9}\end{array}$ & $\begin{array}{c}0 \\
3.7 \times 10^{2}\end{array}$ & $\begin{array}{c}52 \\
6.1 \times 10^{11}\end{array}$ \\
\hline
\end{tabular}


